\title{
ЕМПАТІЯ В КОНТЕКСТІ МОРАЛЬНИХ ПОЧУТТІВ
}

Удк: $159.942+177.7$

\section{Чуйко Галина Василівна}

Кандидат філологічних наук, доцент, доцент кафедри психології Чернівецького національного університету імені Юрія Федьковича, м. Чернівці (Україна)

Анотація. Стаття пов'язана з теоретичним аналізом розуміння феноменів емпатії, провини та сорому в психології, зв'язку між ними, емпіричним дослідженням їх прояву в студентів «допомагаючих» професій, щзо й стало метою иүієї роботи.

Констатується, щзо емпатія як співчуття до людини, яка страждає, співпереживання їи на основі розуміння ї̈ внутрішнього стану та інтуїтивного відууття ситуації, в якій опинилася ияя людина, почуття провини як невдоволення собою через вчинок перед іншою людиною, неузгодженість власної поведінки та моральних норм соиіуму, та сорому (як усвідомлення власної недосконалості у певній ситуаџіï, нездатності виконати поставлене завдання, щцо супроводжується негативними переживаннями через осуд вчинку іншими людьми) є складними психологічними феноменами, пов'язаними з моральністю та совісністю людини, ї̈ здатністю взяти на себе відповідальність за свої погані вчинки.

Зроблено висновок, щуо емпатійний розвиток майбутніх медиків частіше схиляє їх до переживання почуття сорому, тоді як психологи з розвинутою емпатією у в однаковій мірі переживають обидва моральні почуття: провину та сором, - щуо сприяє розвитку їх совісності та відповідальності за свої вчинки.

Ключові слова: емпатія, провина, сором, відповідальність, моральність, совісність.

Постановка проблеми і актуальність дослідження. Важливість проблеми поваги до буття й індивідуальності людини традиційно постулюється як психологією і етикою, так i нормами суспільної моральності, проте до різних аспектів iї аналізу наука звертається все ж недостатньо, зважаючи на іiі масштабність i значимість для життя і розвитку особистості та гуманного, центрованого на цінності кожної окремої людини, суспільства. При цьому складовими совісності та моральності людини вважаються переживання емоцій провини та сорому і емпатійність особистості (iї здатність до співчуття та співпереживання, бажання допомогти тому, хто цього потребує, хто у біді).

Аналіз досліджень і публікацій. Про- 
блема емпатії є досить досліджуваною психології, так, до іiі аналізу зверталися: К. Роджерс, І. Ялом, І. М. Юсупов, В. В. Бойко, Т. П. Гаврилова, Є. П. Ільїн, Є. А. Троїцька, Т. І. Пашукова, А. Меграбіан, Л. П. Журавльова та ін., тоді як наукових робіт, присвячених вивченню моральних почуттів - провини та сорому - значно менше; зокрема iï розглядали такі науковці, як К. Ізард, Р. Бенедикт, I. Ялом, I. А. Бєлік, С. П. Ільїн, Дж. Тангней, Ю. Н. Долгов, О. В. Царькова, О. М. Молчанова та ін.

Емпатія (від грець. pathos - «сильне і глибоке почуття, близьке до страждання», em - префікс, що означає «спрямування всередину») - таке духовне єднання особистостей, коли одна людина настільки проникається переживаннями іншої, що тимчасово ототожнюється з нею, ніби розчиняючись в ній [6, с. 82].

Т. Д. Карягина схильна охарактеризувати емпатію як «специфічно людське, олюднюючи пізнання і ставлення, співучасть, що зцілює» [7]; Т. М. Лазоренко розуміє пї як «глибоке і безпомилкове сприйняття внутрішнього світу іншої людини, iї прихованих емоцій і смислових відтінків, емоційне співзвуччя з іiі переживаннями, використання всієї глибини розуміння цієї людини не в своїх, а в ії інтересах» [9].

На думку С. А. Троїцької, «в основі емпатії лежить не просто емоційне зараження, але ще й розуміння почуттів і думок іншої людини, яке полегшується у випадку схожості чи знайомства людей» [16, с. 59].

T. І. Пашукова досить доречно (вслід за О. О. Бодальовим) підкреслює роль уяви в емпатійному сприйнятті іншої людини для «доповнення своїми уявленнями браку інформації», «оскільки для розуміння характеру i причин переживань об'єкта емпатії сприйнятої вербальної і невербальної інформації зазвичай буває недостатньо» [13, с. 205], - зазначимо, ці «уява» та «уявлення» у випадку емпатії частіше мимовільні, крім того, для деяких людей значно важливішою тут буде не уява, а інтуїція.

На думку К. Роджерса, «емпатійний спосіб спілкування з іншою особистістю має кілька граней. Він передбачає входження в особистий світ іншого і перебування в ньому «як вдома». Він включає постійну чутливість до змінюваних переживань іншого ... до всього, що відчуває він чи вона. Це означає тимчасове життя іншим життям, делікатне перебування в ньому без оцінювання та засудження ... уловлювання того, що інший сам заледве усвідомлює. Але при цьому відсутня спроба відкрити цілком неусвідомлювані почуття, оскільки вони можуть виявитися травмуючими ... Це передбачає часті звертання до іншого для перевірки своїх вражень і уважне прислухання до отримуваних відповідей» [14].

За І. Яломом, емпатійно співпереживати означає «увійти в особистий світ іншого і познайомитися із цим світом, жити в житті іншої людини і відчувати іï сенси і пережи- 
вання» [17].

Д. Бетсон, визначивши два основні питання, які стосуються емпатії (як хтось може знати, що думає чи переживає інший, та що спонукає одну людину відповідати з чутливістю та турботою на страждання іншої?), і які окремі вчені вважають непов'язаними, та пояснивши, що відповіддю на перше є те, що ми уявляємо себе у ситуації іншої людини і «прочитуємо» iï внутрішній стан, виходячи 3 нашого власного (наших переживань), а на друге - те, що емпатійні почуття до інших людей (такі, як симпатія, співчуття, ніжність і схожі) зменшують страждання людей, до яких відчувають емпатію, виділив вісім взаємопов'язаних, але різних феноменів, що стосуються емпатії:

1) знання внутрішнього стану іншої людини, включаючи іï думки та почуття;

2) «прийняття» стану іншої людини чи реакція нервової системи у відповідь на ту, що проявляється в іншої людини;

3) переживати ті самі почуття, що й інша людина;

4) інтуїтивне відчуття ситуації чи проектування себе в неї;

5) уявити, як почувається і що думає інша людина;

6) уявлення себе (своїх думок та почуттів) у аналогічні ситуації (на місці іншого);

7) співчуття до людини, яка страждає;

8) викликає та посилює співчуття до тих, хто страждає [18].
Мета цієї статті - теоретично проаналізувати розуміння феноменів емпатії, провини та сорому в психології та емпірично дослідити їх вияв у студентів «допомагаючих» професій і можливий зв'язок між ними.

Виклад основного матеріалу. На думку Н. Ф. Желудової, емпатія «безпосередньо регулює взаємостосунки людей і багато в чому визначає моральні якості людини», хоча вірним до певної міри буде і зворотне: моральна вихованість стимулює емпатійні властивості особистості [3]. Крім того, оскільки мета емпатії полягає в тому, щоб сприяти благополуччю іншої людини, вона $є$ альтруїстичним мотивом допомагаючої поведінки [15, с. 587].

Дефіцит емпатії, як стверджує Д. Лабір, перетворює людей на егоїстів, а без емпатії людство взагалі «приречене на вимирання», оскільки, розучившись спілкуватися та не відчуваючи в цьому потреби, нам не вдасться вирішити жодної серйозної проблеми [11].

Зазначимо, що Н. Макаревич, яка висвітлює погляди Д. Лабіра, підсумовуючи їх, виявляє власну незгоду з позицією вченого, мотивуючи тим, що «вимирання від байдужості» у світі, який давно наповнений цинічним ставленням до інших, - «слабкий привід» для неспокою внаслідок катастрофічного браку емпатії. Більш того, саме цинізм авторкою спокійно й не аргументовано витлумачується як психологічний захисний механізм, що «допомагає вижити» [11]. На нашу думку, у світі без емпатії, «захлеснутому» цинізмом, 
цинік насправді збільшує свої шанси вижити, але не жити, адже, щоб жити, відчуваючи задоволення від життя, і почуватися благополучно циніки та люди, не обтяжені муками совісті, використовують саме емпатів.

Емпатія, на думку ії відомої дослідниці Т. П. Гаврилової, проявляється у двох формах: співпереживанні та співчутті. Співпереживання - це переживання суб'єктом тих самих почуттів, які відчуває інша людина. Воно засноване переважно на минулому досвіді людини i пов'язане $з$ потребою власного благополуччя, iii інтересами, тому більш імпульсивне та інтенсивне. Співчуття - це чуйне, співчутливе ставлення до переживань, страждань, нещастя іншої людини (вираження жалю, співчуття і т. ін.). Воно базується на розумінні неблагополуччя іншої людини і пов'язується з її потребами та інтересами [6]. Н. Ф. Желудова додає це одну форму емпатії - сприяння [3].

Дж. Іганом виділені три рівні емпатії: найглибший рівень - це «спосіб буття» (way of being), за К. Роджерсом, спосіб «бути разом» 3 іншою людиною, розуміти нюанси й особливості іiі внутрішнього світу; по-друге, емпатія - це спосіб професійної присутності та професійного контакту з клієнтом зі складним і різноманітним внутрішнім життям; по-третє, емпатія - це комунікативна навичка, використанню якої можна навчитися, однак 3 неї не буде користі, поки вона не стане «вираженням способу буття консультанта» [4].

Сучасна психологія виділяє кілька видів емпатії: емоційну, когнітивну (раціональну), інтуїтивну, поведінкову, предикативну, - проте, на наш погляд, розуміючи емпатію як складне комплексне за суттю прояву явище, це, скоріше, не стільки окремі види емпатії, скільки різні складові цілісного процесу емпатії, причому, залежно як від ситуації, так і від особистості, домінуючими в емпатійному процесі можуть виявитися різні його складові, які в цілому формують феномен емпатії. Тому ми відзначаємо раціональність і певну справедливість виділення В.В. Бойко раціонального, емоційного й інтуїтивного каналів (а не видів) емпатійних здібностей особистості.

Провина - одна з виділених К. Ізардом базових емоцій. Згідно $Є$. П. Ільїна, «психологічне розуміння провини полягає у переживанні незадоволення собою, пов'язаного 3 виявленням людиною неузгодженості між власною поведінкою та прийнятими моральними нормами» [6, с. 176].

I. Ялом зазначає, що «традиційно провина визначається як почуття, що породжується реальним чи уявним проступком проти іншої людини», що переживається як дискомфорт і тривога, поєднані з відчуттям людини, що вона «погана», проте в екзистенційній філософії та психології С. Кьєркєгора, О. Ранка та П. Тілліха джерелом провини є непроживання людиною даного їй життя [17].

Крім того, західні психологи виокремлюють провину-стан і провину-рису особистості, тоді як у вітчизняній психології йдеться про провину як базову емоцію та про совіс- 
ність як моральну характеристику особистості [6].

Провина - це результат роботи свідомості людини, що переживається як конфлікт із совістю та результат невиконання внутрішніх настанов [2], як інтенсивне і болісне почуття власної неправоти по відношенню до тих (того), перед ким (чим) провинилася людина [5].

Згідно Ю. М. Долгова, провина проявляється як переживання людиною ставлення до своєї поведінки, дії чи бездіяльності, неправильних з їі погляду, що означає розуміння нею недопустимості цього [2].

Д. Осабел зазначає, що емоція провини «лежить в основі розвитку й зміцнення соціальних норм і тому неминуче представлена у всіх культурах за мінімально сприятливих для цього умов. Він назвав три психологічні передумови розвитку емоції провини: 1) прийняття загальних (спільних) моральних цінностей; 2) інтерналізація цих цінностей; 3) здатність до самокритики, розвинута настільки, щоб сприймати протиріччя між реальною поведінкою та інтерналізованими цінностями $[5 ; 6]$.

Провина виникає у людини в ситуаціях, пов'язаних з усвідомленням своєї відповідальності, яка, за К. Ізардом, є «ядром структури совісті» і свідченням «моральної поведінки», як перед іншими людьми, так і перед собою, за шкоду, заподіяну навколишньому, чи порушення моральних норм соціуму [5].

Переживаючи провину, людина, 3 од- ного боку, робить все, щоб про неблаговидний вчинок не дізналися інші, 3 іншого, - може настільки бажати виправити учинене чи применшити його негативні наслідки, що навіть ладна віддати значно більше, компенсуючи збитки як відплату за свій прорахунок.

Д. Унгер вважає провину двокомпонентною емоцією, де першим компонентом є вербально-оціночна реакція людини, що свідчить про усвідомлення нею помилковості вчиненого, тобто каяття, що супроводжується негативним ставленням до себе і самозвинуваченням за порушення власних моральних принципів. У результаті з'являється другий компонент провини: вегетативно-вісцеральна реакція 3 цілою гамою стійких негативних переживань, найсуттєвішим з яких є муки совісті [6].

I. А. Бєлік розглядає провину як чотирикомпонентне утворення, що складається 3: 1) емоційного (дисфоричні переживання); 2) когнітивного (усвідомлення вчинку і його наслідків); 3) мотиваційного (бажання виправити вчинене) та 4) психосоматичного (неприємні фізичні відчуття) компонентів [6].

Ми вважаємо більш точною структуру переживання провини I. А. Бєлік, оскільки, перш, ніж усвідомити аморальність зробленого, що приведе до каяття та його вербалізації, людина має пережити (емоційно відреагувати) цю подію через відчуття негативних емоцій; проте наступним (за порядком появи) у почутті провини варто визнати саме компонент психосоматичний, і тільки потім може 
«включитися» когнітивний і як його результат - мотиваційний i навіть поведінковий (якщо неможливо виправити ситуацію, то хоча б «відкупитися» від неї).

На думку А. Кемпінськи та Ф. Перлза, провина тісно пов'язана з переживанням образи, оскільки вони мають спільну основу - прагнення до справедливості, а «різниця полягає лише в тому, що в одному випадку присуд приймається, а в іншому - проти нього борються», причому «провина і образа можуть переходити одна в іншу» [6, с.180].

Ми готові погодитися, що образа і провина здатні до взаємоперетворення, але, на нашу думку, якщо нас образила близька нам людина, з часом ми починаємо почувати провину або через те, що «довели» iii до цього, або, що думали, що вона взагалі на це здатна (тоді як щодо психологічно чужої людини таких почуттів і думок не виникає), коли ж ми провинилися перед чужою людиною, і нам здається, що вона може це зрозуміти, ми перетворюємо це на почуття образи як через те, що вона це «спровокувала», так і для того, щоб ситуація не привела нас до почуття соромy.

Варто додати, що Д. Вайсс виділив п'ять типів провини: адаптивну та чотири типи дезадаптивної провини: того, хто вижив; гіпервідповідальності; відокремлення та ненависті до себе, які, за суттю, відображають причини й умови виникнення провини [6]. Зазначимо, що дещо специфічною, і тому відокрем- леною від решти виявляється екзистенційна («онтологічна») провина, тип якої виділений екзистенційною психологією (зокрема, I. Яломом і Р. Меєм). На думку Д. Ханна, поняття екзистенційної провини варто застосовувати лише в тих випадках, коли поведінка людини суперечить прийнятим самою людиною стандартам поведінки та іiі цінностям, поставленим та досягнутим цілям [5].

Р. Бенедикт, досліджуючи суспільнокультурний аспект переживання провини, висловила думку про те, що суспільство, яке будується на вихованні совісті у кожного свого члена, орієнтуючи на абсолютні критерії моралі, представлятиме собою «культуру провини», яка стає особистісною. Таке суспільство виробляє спільні правила поведінки на основі вищого обов'язку, які $є$ універсальними для всіх громадян [2]. Культуру провини, згідно Р. Бенедикт, визначать: індивідуальна оцінка людиною своїх вчинків; поняття совісті як самооцінки людиною своїх дій; моральне покарання за помилкові дії - муки совісті; можливість виправити помилку, відновити репутацію; необхідність чинити, орієнтуючись на особисті правила моралі та моральності; наявність покарання як способу спокути провини.

Отже, провина $є$ складним психологічним феноменом, тісно пов'язаним 3 моральністю і совісністю людини, її здатністю взяти на себе відповідальність за свої неблаговидні вчинки. Суспільство, якому незнайоме почуття провини, на думку К. Ізарда, до якої ми 
приєднуємося, «виявилося б найбільш беззаконним і найбільш небезпечним суспільством у світі», адже саме почуття провини сприяє підтриманню згоди з приводу дотримання суспільних норм і виконання законів [5].

Базову емоцію сорому К. Ізард вважає усвідомленням людиною «власного невміння, непридатності чи неадекватності в певній ситуації чи при виконання певного завдання, що супроводжується негативними переживаннями, - засмученням, неспокоєм чи тривогою» [5].

С. Томкінс описує сором як емоцію найвищої рефлексії, коли стирається межа між суб'єктом і об'єктом сорому, і людина занурюється до болісного самоусвідомлення та саморозуміння [5; 6].

Ю. М. Долгов змальовує переживання сорому як незадоволеності собою, тяжкий неспокій, жаль через вчинене, осуд своєї поведінки чи поведінки інших людей [2], яке народжується внаслідок реальної чи вдаваної втрати поваги оточуючих. Сором відноситься до відчуття власної особистості: ми переживаємо сором, коли вважаємо, що негідні чогось чи маємо якусь ваду [10], через що потрапляємо у стан безпомічності й безнадії, що заставляє уникати інших людей. При цьому поріг емоції сорому визначається тим, наскільки чутлива людина до ставлення до себе та думки про себе з боку оточуючих [6].

Д. Осабел вважає, що в основі сорому лежить осуд, зовнішній за походженням, при- чому він може бути і лише уявним. Передумовою для морального сорому (а вчений виділяє також «неморальний сором» як наслідок вчинків, що не суперечать моральним нормам) $є$ осуд вчинку іншими людьми 3 позицій моральності, причому зовсім не обов'язково, щоб людини поділяла думку оточуючих, що ії вчинок негожий [6].

При соромі уся свідомість людини заповнюється нею самою, вона усвідомлює лише себе чи лише ті риси, які видаються їй у цей момент неадекватними, навіть непристойними; ніби те, що глибоко приховувалося, несподівано виявилося виставленим на загальний огляд. При цьому людина відчуває свою загальну неспроможність, некомпетентність [5; 6] і починає краще розуміти, як виглядає в очах інших [5].

Зрозуміти, що людина соромиться, можна за такими ознаками: спонукання зіщулитися чи сховатися; бажання зникнути; відчуття, що все тіло костеніє; відчуття, що говорити важче, ніж зазвичай [10].

За дослідженнями Р. Бенедикт, у культурах, де належність до якоїсь соціальної групи означає більше, ніж зберігати власну індивідуальність, де поведінка індивіда диктується групою («колективістських»), основним психологічним механізмом суспільного контролю буде сором, і кожен 3 дитинства порівнюватиме свої вчинки з оцінками оточуючих і буде діяти так, щоб заслужити їх схвалення. Вчена називає такі культури культурами сорому, в 
соціальній системі яких не варто турбуватися про вчинок, «поки люди не дізналися» [2].

Культура сорому характеризується: запропонованими строгими ритуалами, дотримуватися яких необхідно усім без виключення; порушення ритуалу - це ганьба для людини, спокутувати яку можна лише ще більш точним дотриманням ритуалу; сильною оціночною залежністю: поведінку людини оцінює не вона сама, а соціум; первинністю інтересів групи, колективу, до яких належить індивід; інтереси конкретної людини - другорядні; розумінням того, що моральність полягає в тому, щоб не чинити гріх, а не в тому, щоб, здійснивши зло, покаятися і спокутувати його; неможливістю замолювати гріх, відсутністю сповіді; презирством близьких і рідних, групи, до якої належить індивід, що вважається моральним покаранням за неправедну поведінку; необхідністю чинити і діяти, виходячи з інтересів групи [2].

Не зважаючи на те, що обидва почуття (провина і сором) переживаються схоже, між ними існують і суттєві відмінності. Обидва вони пов'язані з вчинками, які для нас і соціуму неприйнятні та недопустимі. Провина, муки совісті виникають, якщо людина чинить непорядно чи незаконно, тоді як сором - через те, що інші роблять $з$ людиною, якщо суспільство вважає це гріхом чи злочином, ніби проектуючи поганий вчинок іншої людини на жертву [1]. Крім того, сором з'являється, коли людина виявляється«не такою», якою іiї можуть прийняти, схвалити й полюбити інші люди. Почуття ж провини містить частку гніву через те, що людину «спіймали» на чомусь негідному. Обидві емоції зумовлюють появу почуття власної негідності, безпомічності та безнадійності, що зумовлює появу руйнівних негативних емоцій та переживання стресу [2; $5 ; 8]$.

O. Моурер (і ми також) підтримує найбільш поширену думку стосовно різниці між емоціями сорому та провини, вважаючи, що необхідною умовою для переживання сорому $€$ присутність стороннього глядача, тоді як переживання провини може «наздогнати» людину і на самоті, і за відсутності актуального джерела покарання [5].

Нам здається, що, хоча провину людина переживає «з власної ініціативи», а сором через іншу людину (чи за неї), прояв вини більше зорієнтований на інших, їх оцінку, і людина намагається виправитися і не допустити повторення ситуації, тоді як сором - на саму людину (суб'єктивний вияв переживання), іiі зміну задля себе самої.

Д. Тангней зазначає, що провина викликає бажання вибачитися, висповідатися, а сором - бажання сховатися, втекти. Провина пов'язана $з$ негативною оцінкою своєї конкретної поведінки, тоді як сором - 3 негативною оцінкою своєї особистості. Переживання сорому переважно пов'язане із соціальною терпимістю, переживання провини - із соціальною емпатією [6].

Крім того, якщо емоція сорому тимча- 
сово затуманює розум (людина ніби втрачає здатність мислити і говорити), то емоція провини, навпаки, стимулює мисленнєві процеси (думки ніби самі з'являються в голові, навіть якщо людина намагається думати про інше, вона мислено повертається до вчиненого), пов'язані з усвідомленням провинності та 3 перебором можливостей для виправлення ситуації [5]. Сором, на думку вчених, ближчий до емоцій, це інтенсивніше переживання, ніж провина, яка повинна бути усвідомлена і відрефлексована (містить когнітивний компонент).

Згідно С. Г. Якобсона, якісна відмінність між переживанням почуттів провини та сорому полягає в тому, що сором пов'язаний 3 першим рівнем моральної регуляції, де «останньою інстанцією», що визначає, «добре» чи «погано» чинить людина, виступають реальні «інші», тоді як почуття провини $\epsilon$ складнішим переживанням, оскільки співвідноситься не лише з можливими оцінками конкретних людей «тут-і-тепер», але й 3 «повинним», тим, як має бути (як інтерналізованим ідеалом поведінки) [12].

Цікавою, хоча й не беззаперечною, $є$ думка О. Гусєвої, згідно якої емоції провини та сорому - лише маски, за якими приховуються страх і агресія як «соціально непристойні реакції» на події, вчинки чи бездіяльність людини [1].

Відповідно до мети статті, ми провели емпіричне дослідження, у якому використову- валися методики діагностики рівня емпатійних здібностей В. В. Бойко та «Вимірювання провини та сорому» (Test of Self-Conscious Affect (TOSCA)) Дж. П. Тангней, а вибірками стати студенти старших курсів: майбутні медики $\left(\mathrm{n}_{\mathrm{m}}=38\right)$ та психологи $\left(\mathrm{n}_{\Pi}=38\right)$.

Результати дослідження виявили: у вибірці медиків переважаючим $\epsilon$ знижений рівень емпатії - у 63,16 \% опитаних, ще у 21,05 \% майбутніх медиків - середній рівень показника і в 2,63 \% - високий, доповнюваний 13,16 \% вибірки 3 дуже низьким рівнем емпатії; серед складових емпатії переважають установка та проникаюча здатність до емпатичного сприйняття (середні - 3,72 та 3,4 балів), тоді як недостатньо розвинутими виявляються інтуїтивний канал $(2,43$ балів) та ідентифікація в емпатії (2,86 балів); у вибірці психологів також домінує знижений рівень емпатійних здібностей - у 52,63 \% досліджуваних, майже така ж частина опитаних виявили середній рівень емпатії, і лише 5,26 \% - надто низький; за складовими показника емпатійності, переважають розвиток емоційного каналу та установки в емпатії (середні - 3,76 та 3,79 балів), дещо відстає прояв інтуїтивного каналу в емпатії (2,89 балів). Порівняння вибірок за методикою В. В. Бойка показує як ліпший розвиток емпатійних здібностей у цілому в майбутніх психологів - середні - 20,71 балів проти 18,4 - у медиків, так і майже всіх складових емпатії (виключаючи проникаючу здатність, яка у вибірці медиків розвинута мінімально 
краще: середні - 3,4 проти 3,26 балів).

За методикою Дж. Тангней, сильніше провину і сором переживають майбутні психологи (середні - 57,87 та 40,71 балів); у медиків - 49,4 та 35,81 балів відповідно, тоді як більш екстернальними і відчуженими є медики (середні - 35,22 та 27,95 балів); у психологів - 34,87 та 25,71 балів; за альфа-гордістю вибірки цілком співставні, бета-гордість дещо сильніше проявляється у психологів (16,71 балів), у медиків - 16,4 балів; високий рівень переживання провини майбутніми психологами - у 89,47 \% вибірки; у медиків - дещо менше, ніж середній (у 47,37 \% та 50 \% відповідно); у переживанні сорому рівневі показники вибірок схожі.

Кореляційний аналіз виявив існування значимих кореляційних зв'язків в обох вибірках. Так, у вибірці медиків показник провини корелює 3 інтуїтивним каналом емпатії (r = $0,33)$, сорому - 3 емоційним та інтуїтивним каналами $(\mathrm{r}=0,62$ та $\mathrm{r}=0,33)$, установкою в емпатії $(r=0,35)$ і загальним показником емпатії $(\mathrm{r}=0,47)$; у вибірці психологів провина пов'язана з раціональним $(\mathrm{r}=-0,40)$, емоційним $(\mathrm{r}=0,42)$ та інтуїтивним $(\mathrm{r}=0,33)$ каналами емпатії, проникаючою здатністю в емпатії $(\mathrm{r}=-0,48)$; показник сорому 3 емоційним ( $\mathrm{r}=0,53)$, інтуїтивним $(\mathrm{r}=0,34)$ каналами та проникаючою здатністю в емпатії $(\mathrm{r}=-0,66)$. Цікаво також, що, якщо медикам гордість «допомагає» бути емпатійними (позитивна кореляція), то психологам, навпа- ки, шкодить (негативний кореляційний зв'язок), що, можливо, пояснюється специфікою внутрішнього змісту цих професій. Зазначимо, що між показниками провини та сорому існує позитивний кореляційний зв'язок: у вибірці медиків $-\mathrm{r}=0,53$; психологів $-\mathrm{r}=0,64$.

Застосування U-критерію Манна-Уінті дозволило нам виявити різницю між вибірками: майбутні психологи статистично значимо сильніше переживають почуття провини, $\epsilon$ більш емпатійними в цілому та легше ідентифікують себе 3 людьми, яким співчувають, ніж майбутні медики (при р $[0,000011 ; 0,035])$.

Висновки. Емпатія - складне, комплексне психічне явище, в основі якого - співчуття та співпереживання іншій людині, яка потрапила у біду, вміння подивитися на ситуацію iii очима, поставивши себе на іiі місце і відчувши ії внутрішній світ, як власний, та зрозуміти iii стан і переживання; що реалізується у бажанні їй допомогти.

Почуття провини виникає, коли ми робимо щось «не так» (як, з нашого погляду, було б потрібно, за що відчуваємо власну відповідальність), навіть, якщо це нам лише здається; тоді як сором ми відчуваємо перед іншими людьми чи собою, якщо вочевидь не виправдали їх очікувань і сподівань щодо нас, зненацька виявившись нездатними відповідати нормативним вимогам соціуму (зовнішнім) (чи, навпаки, вони не виправдали наших надій i уявлень про них).

Отже, провина є складним психологіч- 
ним феноменом, тісно пов'язаним з моральністю і совісністю людини, їі здатністю взяти на себе відповідальність за свої неблаговидні вчинки. Після сорому, провина - найважливіший фактор виховання соціальної відповідальності особистості, а її розвиток і становлення совісності та моральності людини - найважливіші кроки на шляху психосоціального розвитку особистості.

Згідно результатів емпіричного дослідження, емпатійність майбутніх медиків може схилити їх до переживання почуття сорому, тих же з них, у кого розвинута інтуїція в емпатії, - до відчуття провини через зроблене, тоді як майбутні психологи 3 розвинутими емоційним та інтуїтивним каналами в емпатії, хто не покладається на когнітивну емпатію та проникаючу здатність раціональної емпатії, в однаковій мірі переживають обидва моральні почуття: провину та сором, - що сприяє розвитку їх совісності та відповідальності за свої вчинки.

\section{Перспективу подальших розвідок у} напрямку дослідження вбачаємо в аналізі зв'язку психологічних особливостей особистості 3 переживанням нею моральних почуттів.

\section{Список використаних джерел:}

1. Гусева O. Чувство вины и стыда: как в психике появляется то, чего там быть не должно [Электронный ресурс] / О.Гусева. - Режим доступа: https:// psychologytoday.ru/public/chuvstvo-viny-i-styda-kak-v- psikhike-poyavlyaetsya-to-chego-tam-byt-ne-dolzhno/.

2. Долгов Ю. Н. Вина и стыд как социальные чувства [Электронный ресурс] / Ю.Н. Долгов // Личность, семья и общество: вопросы педагогии и психологии: сб. ст. по матер. XXXIII междунар. науч.-практ. конф. - № 10(34). - Новосибирск: СибАК, 2013. - Режим доступа: https://sibac.info/conf/pedagog/xxxiii/34374.

3. Желудова Н. Ф. Эмпатия ? Путь к ненасилию в современном обществе [Электронный ресурс] / Н.Ф. Желудова. - Режим доступа: https:// rusoir.ru/03print/03print-05/03 print-05-28/.

4. Иган Дж. Базисная эмпатия как коммуникативный навык [Электронный ресурс] / Дж.Иган // Журнал практической психологии и психоанализа. - 2001. - № 1. Режим доступа : http://www.psyjournal.ru.

5. Изард.К. Э. Психология эмоций / К.Э. Изард. - СПб.: Питер, 2007. - 474 с. - (Серия «Мастера психологии»).

6. Ильин Е. П. Психология общения и межличностных отношений / Е.П. Ильин. - СПб.: Питер, 2009. - 304 с. (Серия «Мастера психологии»).

7. Карягина Т. Д. Эволюция понятия «эмпатия» в психологии: дис. ... канд. психол. наук : 19.00.01 [Электронный ресурс] / Татьяна Дмитриевна Карягина. - М.: МГППУ, 2013. - 175 с. - Режим доступа: http:// www.dissercat.com/content/evolyutsiya-ponyatiyaempatiya-v-psikhologii.

8. Колберт Д. Смертельные эмоции / Д.Колберт. - М.: Триада, 2009. - 304 с.

9. Лазоренко T. Н. Роль эмпатии в профессиональной деятельности психологов [Электронный ресурс] / Т.Н. Лазоренко, А.M. Ананьев // Journal of Psychology. Special Pedagogy. Social Work (PSPSW). - Vol. 46. - Iss. 1. - 2017. - Режим доступа: http://psihologie.upsc.md 10. Лэйни М. Преимущества интровертов / М.Лэйни. М.: ООО «Манн, Иванов и Фербер», 2013. - 187 с. 11. Макаревич H. Человечество вымрет от недостатка эмпатии [Электронный ресурс] / Ника Макаревич. Режим доступа: https://www.jv.ru/news/ psikhologhiia/15823-chelovechestvo-vimret-ot-nedostatkaempatii.html. 
12. Макогон И. К. Моральные эмоции и регуляция поведения [Электронный ресурс] / И.К. Макогон, С.Е. Ениколопов. - Режим доступа: http:// scienceandeducation.pdpu.edu.ua/ doc/2009/8_2009/7.pdf.pdf.

13. Пашукова Т. И. Механизмы и функции эмпатии / Т.И. Пашукова, Е.А. Троицкая [Электронный ресурс] // Вестник МГЛУ. - 2010. - № 586. - Режим доступа: URL: https://cyberleninka.ru/article/n/mehanizmy-i-funktsii -empatii.

14. Роджерс K. Эмпатия // Психология мотивации и эмоций / Под ред. Ю. Б. Гиппенрейтер, М. В. Фаликман. - М.: ЧеРо, 2002. - С. 428-430.

15. Социальная психология / Ш.Тейлор, Л.Пипло, Д.Сирс. - СПб.: Питер, 2004. - 767 с. - (Серия «Мастера психологии»).

16. Трочцкая E. A. Концепция эмпатии в зарубежной психологии конца XX - начала XXI века / Е.А. Троицкая // Вестник МГЛУ. - 2011. - Вып.7(613). - С.52-64.

17. Ялом И. Экзистенциальная психотерапия / И. Ялом. - М.: Класс, 1999. - 576 с.

18. Batson D. These things called empathy: eight related but distinct phenomena / D. Batson // The Social Neuroscience of Empathy / J. Decety \& W. Ickes (Eds.). - Cambridge, MA : MIT Press, 2009. - P.3-15.

\section{References (Transliteration):}

1. Guseva O. Chuvstvo viny i styda: kak v psihike pojavljaetsja to, chego tam byt' ne dolzhno [Jelektronnyj resurs] / O.Guseva. - Rezhim dostupa: https:// psychologytoday.ru/public/chuvstvo-viny-i-styda-kak-vpsikhike-poyavlyaetsya-to-chego-tam-byt-ne-dolzhno/.

2. Dolgov Ju. N. Vina i styd kak social'nye chuvstva [Jelektronnyj resurs] / Ju.N. Dolgov // Lichnost', sem'ja i obshhestvo: voprosy pedagogii i psihologii: sb. st. po mater. HHHIII mezhdunar. nauch.- prakt. konf. -№ 10 (34). - Novosibirsk: SibAK, 2013. - Rezhim dostupa: https://sibac.info/conf/pedagog/xxxiii/34374.

3. Zheludova N. F. Jempatija ? Put' $\mathrm{k}$ nenasiliju $\mathrm{v}$ sovremennom obshhestve [Jelektronnyj resurs] / N.F. Zheludova. - Rezhim dostupa: https:// rusoir.ru/03print/03print-05/03print-05-28/.

4. Igan Dzh. Bazisnaja jempatija kak kommunikativnyj navyk [Jelektronnyj resurs] / Dzh.Igan // Zhurnal prakticheskoj psihologii i psihoanaliza. - 2001. - № 1. Rezhim dostupa : http://www.psyjournal.ru.

5. Izard K. Je. Psihologija jemocij / K.Je. Izard. - SPb.: Piter, 2007. - 474 s. - (Serija «Mastera psihologii»).

6. Il'in E. P. Psihologija obshhenija i mezhlichnostnyh otnoshenij / E.P. Il'in. - SPb.: Piter, 2009. - 304 s. - (Serija «Mastera psihologii»).

7. Karjagina T. D. Jevoljucija ponjatija «jempatija» v psihologii: dis. ... kand. psihol. nauk : 19.00.01 [Jelektronnyj resurs] / Tat'jana Dmitrievna Karjagina. - M.: MGPPU, 2013. - 175 s. - Rezhim dostupa: http:// www.dissercat.com/content/evolyutsiya-ponyatiyaempatiya-v-psikhologii.

8. Kolbert D. Smertel'nye jemocii / D.Kolbert. - M.: Triada, 2009. - $304 \mathrm{~s}$.

9. Lazorenko T. N. Rol' jempatii v professional'noj dejatel'nosti psihologov [Jelektronnyj resurs] / T.N. Lazorenko, A.M. Anan'ev // Journal of Psychology. - Special Pedagogy. Social Work (PSPSW). - Vol. 46. - Iss. 1. 2017. - Rezhim dostupa: http://psihologie.upsc.md.

10. Ljejni M. Preimushhestva introvertov / M.Ljejni. - M.: OOO «Mann, Ivanov i Ferber», 2013. - 187 s.

11. Makarevich $N$. Chelovechestvo vymret ot nedostatka jempatii [Jelektronnyj resurs] / Nika Makarevich. - Rezhim dostupa: https://www.jv.ru/news/psikhologhiia/15823chelovechestvo-vimret-ot-nedostatka-empatii.html.

12. Makogon I. K. Moral'nye jemocii i reguljacija povedenija [Jelektronnyj resurs] / I.K. Makogon, S.E. Enikolopov. - $\quad$ Rezhim dostupa: http:// scienceandeducation.pdpu.edu.ua/ doc/2009/8_2009/7.pdf.pdf.

13. Pashukova T. I. Mehanizmy i funkcii jempatii / T.I. Pashukova, E.A. Troickaja [Jelektronnyj resurs] // Vestnik MGLU. - 2010. - № 586. - Rezhim dostupa: URL: https:// cyberleninka.ru/article/n/mehanizmy-i-funktsii-empatii. 
14. Rodzhers K. Jempatija // Psihologija motivacii i jemocij / Pod red. Ju.B. Gippenrejter, M.V. Falikman. M.: CheRo, 2002. - S. 428-430.

15. Social'naja psihologija / Sh.Tejlor, L.Piplo, D.Sirs. SPb.: Piter, 2004. - 767 s. - (Serija «Mastera psihologii»).

16. Troickaja E. A. Koncepcija jempatii v zarubezhnoj psihologii konca $\mathrm{HH}$ - nachala HHI veka / E.A. Troickaja // Vestnik MGLU. - 2011. - Vyp.7(613). - S.5264.

17. Jalom I. Jekzistencial'naja psihoterapija / I.Jalom. - M.: Klass, 1999. - $576 \mathrm{~s}$.

18. Batson D. These things called empathy: eight related but distinct phenomena / D. Batson // The Social Neuroscience of Empathy / J. Decety \& W. Ickes (Eds.). - Cambridge, MA : MIT Press, 2009. - P.3-15.

\section{Chuyko Halyna}

PhD (philological sciences), associate professor of psychology department, Yuriy Fedkovych Chernivtsi National University Chernivtsi (Ukraine)

\section{EMPATHY IN THE CONTEXT OF MORAL FEELINGS}

\begin{abstract}
Article deals with the theoretical analysis of understanding of the phenomena of empathy, guilt and shame in psychology, the relationship between them and the empirical study of their manifestation in the students of "helping" professions; which became the goal of this work.

It is stated that empathy as a condolences for the person suffering, compassion to her on the basis of understanding of her internal state of another person and the intuitive sensation of the situation in which this human appeared, the feeling of guilt as dissatisfaction with himself through
\end{abstract}

the misbehavior before another person, inconsistency of one's own behavior and moral norms of society, and shame (as awareness of one's own imperfection in certain situation, inability to accomplish the task, accompanied by negative experiences through the condemnation of the deed by other people) are the complex psychological phenomena related to morality and conscientiousness of human, his ability to take responsibility for his bad deeds.

It is shown that modern psychology distinguishes several types of empathy: emotional, cognitive (rational), intuitive, behavioral and predicative. However, understanding empathy as a complex and integrated in fact manifestations of the phenomenon, we consider it is not so much separate types of empathy, how many different components of the whole process of empathy. The various components of the empathy, which in general form the phenomenon of empathy, may be dominant in the empathy process, depending on the situation and on the personality.

It is noted that concerning to the difference between the emotions of shame and guilt, we support the opinion that the presence of a third person is a required condition for experience of shame, while the experience of guilt can "overtake" a person both alone and in the absence of an actual source of punishment.

Methods of the measurement of level of empathic abilities (V. V. Boyko) and "Test of Self-Conscious Affect (TOSCA)" J. P. Tangney were used in the research. It was revealed that 
future psychologists are statistically significantly stronger experiencing feeling of guilt, are more empathic in general and more easily identifying themselves with people who sympathize with than future physicians.

It was concluded that development of empathy of future physicians more often incline them to experience the feeling of shame, whereas psychologists with developed empathy are equally experiencing both moral feelings: guilt and shame - which promotes the development of their conscientiousness and responsibility for their deeds.

Key words: empathy, guilt, shame, responsibility, morality, conscientiousness.

\section{Чуйко Галина Васильевна}

Кандидат филологических наук, дочент, доцент кафедры психологии Черновичского национального университета имени Юрия Федьковича, Черновиь (Украина)

\section{ЭМПАТИЯ В КОНТЕКСТЕ НРАВСТВЕННЫХ ЧУВСТВ}

Аннотация. Статья связана с теоретическим анализом понимания феноменов эмпатии, вины и стыда в психологии, связи между ними; эмпирическим исследованием их проявления у студентов «помогающих» профессий, что и стало целью этой работы.

Констатируется, что эмпатия как сочувствие человеку, который страдает, сопереживание ему на основе понимания его внутреннего состояния и интуитивного ощущения ситуации, в которой оказался этот человек; чувство вины как недовольство собой из-за проступка перед другим человеком, несогласованности собственного поведения и моральных норм социума; и стыда (как осознание собственного несовершенства в определенной ситуации, неспособности выполнить поставленную задачу, сопровождаемые негативными переживаниями из-за осуждения поступка другими людьми) являются сложными психологическими феноменами, связанными с нравственностью и совестливостью человека, его способностью взять на себя ответственность за свои плохие поступки.

Показано, что современная психология выделяет несколько видов эмпатии: эмоциональную, когнитивную (рациональную), интуитивную, поведенческую и предикативную. Однако, понимая эмпатию как сложное комплексное по сути проявления явление, мы считаем это не столько отдельными видами эмпатии, сколько различными составляющими целостного процесса эмпатии. В зависимости как от ситуации, так и от личности, доминирующими в емпатийнои процессе могут оказаться различные его составляющие, которые в целом формируют феномен эмпатии.

Отмечается, что в отношении разницы между эмоциями стыда и вины, мы поддерживаем мнение, что необходимым условием для переживания стыда является присутствие постороннего зрителя, тогда как переживание вины может «догнать» человека и в одиночестве, и при отсутствии актуального источника 
наказания.

В исследовании использовались методики диагностики уровня эмпатических способностей (В.В. Бойко) и «Измерение вины и стыда» (Test of Self-Conscious Affect (TOSCA)) Дж.П. Тангней. Выявлено, что будущие психологи статистически значимо сильнее переживают чувство вины, являются более эмпатийными в целом и легче идентифицируют себя с людьми, которым сочувствуют, чем будущие медики.

Сделан вывод, что эмпатийное развитие будущих медиков чаще склоняет их к переживанию чувства стыда, тогда как психологи с развитой эмпатией в равной степени переживают оба нравственные чувства: вину и стыд, - что способствует развитию их совестливости и ответственности за свои поступки.

Ключевые слова: эмпатия, вина, стыд, ответственность, нравственность, совестливость. 